International Journal of Engineering \& Technology, 7 (4.14)(2018) 158-162
International Journal of Engineering \& Technology
SPC
Website: www.sciencepubco.com/index.php/IJET
Research paper

\title{
One-pot Synthesis of Unsymmetrical Diaryliodonium Tetrafluoroborate Salts Bearing an Isoxazole Moiety from Aryl Boronic Acids
}

\author{
M.A.F. Abdul Manan ${ }^{1 *}$, D.B. Cordes ${ }^{2}$, A.M.Z. Slawin ${ }^{2}$ and D. O'Hagan ${ }^{2}$ \\ ${ }^{1}$ Faculty of Applied Sciences, Universiti Teknologi MARA, 40450 Shah Alam, Selangor, Malaysia \\ ${ }^{2}$ EaStCHEM School of Chemistry, University of St Andrews, North Haugh, St Andrews, KY16 9ST, UK \\ *Corresponding author Email: abdfatah@salam.uitm.edu.my
}

\begin{abstract}
Hypervalent iodine compounds exhibit attractive features of low cost, mild and selective reagents in organic synthesis. These reagents serve as environmentally benign alternatives to toxic heavy-metal based oxidants and expensive organometallic catalysts. The practical and simple synthesis of unsymmetrical diaryl iodonium tetrafluoroborate salts is described. This synthetic method has allowed the production of isoxazole tetrafluoroborate salts from readily available aryl boronic acids without an extra anion exchange step in acceptable yields of $45 \%$ and $50 \%$.
\end{abstract}

Keywords: Hypervalent; iodonium; unsymmetrical; isoxazole; tetrafluoroborate

\section{Introduction}

The first organic hypervalent iodine compound, (dichloroiodo) benzene was prepared by German chemist Conrad Willgerodt by reacting iodobenzene with $\mathrm{ICl}_{3}{ }^{1}$. This was rapidly followed by the discovery of other important hypervalent iodine compounds such as (diacetoxyiodo) benzene, iodosylbenzene, 2-iodoxybenzoic acid (IBX) and diaryliodonium salts. ${ }^{2-4}$ The next major contributor to the field was Beringer and co-workers, with their pioneering work to improve synthetic routes and applications of hypervalent iodine compounds for various organic transformations. ${ }^{5}$ The discovery of Dess-Martin periodinane (DMP) as a mild and non-toxic oxidation reagent by Dess and Martin in the 1980s was a major breakthrough in hypervalent iodine chemsistry. ${ }^{6}$ Since then, synthetic chemistry related to such compounds has received considerable attention. According to IUPAC nomenclature, hypervalent iodine compounds are generally classified according to the oxidation state of the iodine and are denoted with a lambda notation. ${ }^{7}$ Diaryliodonium salts are one of the most important $\lambda^{3}$ hypervalent compounds. For example, they have been widely employed as a precursors in fluorination reactions especially in the field of positron emission tomography. ${ }^{8,9}$ The general structure of $\lambda^{3}$-iodane diaryliodonium salts is shown in Figure 1. It is referred to as a symmetrical salt if $\mathrm{R}^{1}=\mathrm{R}^{2}$ and unsymmetrical salt if $\mathrm{R}^{1} \neq \mathrm{R}^{2}$ and can be classified as 8-I-2 cationic species according to the Martin-Arduengo $N-X-L$ rule, with two aryl moieties associated with an anion $\mathrm{X}^{-10,11}$

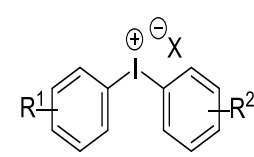

Figure 1: General structure of diaryliodonium salts.
Diaryliodonium salts can be prepared by several different approaches and most of them are carried out under acidic conditions. ${ }^{5,12}$ The widely employed strategy for the synthesis of such compound requires two or three steps, with initial oxidation of the aryl iodide to an iodine(III) compound followed by ligand exchange reaction with an arene or organometallic reagent to afford a diaryiodonium salt. ${ }^{5,13}$ In many cases, anion exchange is required in order to obtain a suitable anion for further reaction. ${ }^{14}$ The one-pot strategy described herein provides access to the preparation of unsymmetrical diaryl iodonium tetrafluoroborate salts in acceptable yields without an extra anion exchange step.

\section{Experimental Section}

\subsection{General experimental procedures}

All the chemicals, reagents and solvents for the synthesis of compounds were analytical grade and used without further purification. NMR spectra were acquired on either Bruker Avance $400\left({ }^{1} \mathrm{H}\right.$ at $400 \mathrm{MHz},{ }^{13} \mathrm{C}$ at $100 \mathrm{MHz},{ }^{19} \mathrm{~F}$ at $\left.376 \mathrm{MHz}\right)$ equipped with BBFO probe, Bruker Avance III HD $500\left({ }^{1} \mathrm{H}\right.$ at $500 \mathrm{MHz}$, ${ }^{13} \mathrm{C}$ at $125 \mathrm{MHz},{ }^{19} \mathrm{~F}$ at $470 \mathrm{MHz}$ ) equipped with $\mathrm{BBFO}$ probe or Bruker Avance III $500\left({ }^{1} \mathrm{H}\right.$ at $500 \mathrm{MHz},{ }^{13} \mathrm{C}$ at $\left.125 \mathrm{MHz}\right)$ equipped with TCI cryoprobe. The chemical shifts $(\delta)$ are reported in parts per million (ppm) and are quoted relative to centre of the residual non-deuterated solvent peak for $\delta_{\mathrm{H}}\left(\mathrm{CDCl}_{3}: 7.26 \mathrm{ppm}\right.$; DMSO: $2.50 \mathrm{ppm})$ and $\delta_{\mathrm{C}}\left(\mathrm{CDCl}_{3}: 77.16 \mathrm{ppm}\right.$; DMSO: 39.52 $\mathrm{ppm})$. Chemical shifts $\delta_{\mathrm{F}}$ are quoted relative to $\mathrm{CFCl}_{3}$ $\left(\delta_{\mathrm{F}} \mathrm{CFCl}_{3}: 0.00 \mathrm{ppm}\right) .{ }^{13} \mathrm{C}$ NMR spectra were recorded using the DEPT $Q$ or UDEFT pulse sequence with broadband ${ }^{1} \mathrm{H}$ decoupling. ${ }^{19} \mathrm{~F}\left\{{ }^{1} \mathrm{H}\right\}$ spectra were recorded with inverse-gating, to avoid errors on the integrals. Coupling constants $(J)$ are given in 
Hertz (Hz). Signal splitting patterns are described as: br s (broad singlet), d (doublet) or $\mathrm{s}$ (singlet). Spectroscopic data were assigned based on the combination of one- and two-dimensional experiments (HSQC and HMBC). IR spectra were recorded using the ATR technique on Shimadzu IR Affinity-1S FTIR spectrometer. High and low resolution mass spectra were recorded at the EPSRC National Mass Spectrometry Service, Swansea or at the University of St Andrews on a Waters Micromass LCT time of flight mass spectrometer coupled to a Waters 2975 HPLC system. Values are reported as a ratio of mass to charge $(\mathrm{m} / \mathrm{z})$.

\subsection{X-ray crystallography}

All diffraction data were collected by using a Rigaku FR-X Ultrahigh brilliance Microfocus RA generator/confocal optics and Rigaku XtaLAB P200 system, with Mo K $\alpha$ radiation $(\lambda=0.71075$ $\AA$ ). Intensity data for all samples were collected using $\omega$ steps accumulating area detector images spanning at least a hemisphere of reciprocal space. All data were corrected for Lorentz polarization effects. A multiscan absorption correction was applied by using CrystalClear ${ }^{15}$ or CrysAlisPro. ${ }^{16}$ Structures were solved by Patterson (PATTY) ${ }^{17}$ or direct (SIR2004, SIR2011) ${ }^{18,19}$ methods and refined by full-matrix least-squares against $\mathrm{F}^{2}$ (SHELXL-2013). ${ }^{20}$ Non-hydrogen atoms were refined anisotropically, and hydrogen atoms were refined using a riding model. All calculations were performed using the CrystalStructure ${ }^{21}$ interface.

\subsection{Synthesis of methyl 3-methoxyisoxazole-5- carboxylate $(2)^{22}$}

$\mathrm{K}_{2} \mathrm{CO}_{3}(2.9 \mathrm{~g}, 21.0 \mathrm{mmol}, 1.5 \mathrm{eq})$ and $\mathrm{CH}_{3} \mathrm{I}(1.3 \mathrm{~mL}, 21.0 \mathrm{mmol}$, 1.5 eq) were added to a solution of methyl 3-hydroxyisoxazole-5-carboxylate (1) $(2.0 \mathrm{~g}, 13.9 \mathrm{mmol}, 1.0 \mathrm{eq})$ in DMF $(10 \mathrm{ml})$ at $0{ }^{\circ} \mathrm{C}$. After $14 \mathrm{~h}$ stirring at $\mathrm{rt}$, the mixture was poured into an ice-cold aqueous solution of $\mathrm{HCl}(0.5 \mathrm{M}, 100 \mathrm{~mL})$ and extracted into $\mathrm{Et}_{2} \mathrm{O}(5 \times 80 \mathrm{~mL})$. The combined organic layers were washed with a saturated aqueous solution of $\mathrm{Na}_{2} \mathrm{CO}_{3}(80$ $\mathrm{mL}$ ), dried over $\mathrm{MgSO}_{4}$, filtered and concentrated under reduced pressure to afford a light yellow crystalline solid, which was purified by silica gel column chromatography (petroleum ether/ $\mathrm{Et}_{2} \mathrm{O}$, 80:20), affording methyl-3-methoxyisoxazole-5carboxylate (2) $(1.45 \mathrm{~g}, 66 \%)$ as colourless crystalline solid: $\mathbf{R}_{\mathbf{f}} 0.71$ (petroleum ether/Et ${ }_{2} \mathrm{O}, 70: 30, \mathrm{UV} / \mathrm{KMnO}_{4}$ ); $\mathbf{m p} 72-73{ }^{\circ} \mathrm{C}$ [Lit. $\left.{ }^{22} 70^{\circ} \mathrm{C}\right] ; \boldsymbol{\delta}_{\mathbf{H}}\left(500 \mathrm{MHz}, \mathrm{CDCl}_{3}\right) 6.53(1 \mathrm{H}, \mathrm{s}, \mathrm{H}-4), 4.02(3 \mathrm{H}$, s, H-8), $3.94(3 \mathrm{H}, \mathrm{s}, \mathrm{H}-7) ; \delta_{\mathrm{C}}\left(125 \mathrm{MHz}, \mathrm{CDCl}_{3}\right) 172.2(\mathrm{C}-3)$, 160.5 (C-5), 157.2 (C-6), 100.8 (C-4), 57.6 (C-8), 53.0 (C-7); HRMS $m / z\left(\mathrm{ESI}^{+}\right)$, found: $[\mathrm{M}+\mathrm{Na}]^{+} 180.0266, \mathrm{C}_{6} \mathrm{H}_{7} \mathrm{NO}_{4} \mathrm{Na}$ requires $[\mathrm{M}+\mathrm{Na}]^{+} 180.0273$. These data are in accordance with the literature. 22

\subsection{Synthesis of 5-hydroxymethyl-3-methoxyisoxazole $(3)^{23}$}

$\mathrm{NaBH}_{4}(1.51 \mathrm{~g}, 40.0 \mathrm{mmol}, 2.5 \mathrm{eq})$ was added to a solution of methyl 3-methoxyisoxazole-5-carboxylate (2) $(2.50 \mathrm{~g}, 16.0 \mathrm{mmol}$, $1.0 \mathrm{eq})$ in $\mathrm{MeOH}(50 \mathrm{~mL})$ at $0{ }^{\circ} \mathrm{C}$. The mixture was stirred at $\mathrm{rt}$ overnight and quenched with saturated solution $\mathrm{NH}_{4} \mathrm{Cl}(40 \mathrm{~mL})$. The reaction mixture was partitioned between water $(50 \mathrm{~mL})$ and EtOAc $(50 \mathrm{~mL})$. The aqueous layer was extracted with EtOAc $(3 \mathrm{x}$ $50 \mathrm{~mL}$ ). The combined organic layers were washed with brine ( 40 $\mathrm{mL}$ ), dried over $\mathrm{MgSO}_{4}$, filtered and concentrated under reduced pressure to afford a pale yellowish oil, which was purified by silica gel column chromatography (petroleum ether/EtOAc, 60:40) to afford 5-hydroxymethyl-3-methoxyisoxazole (3) $(1.75 \mathrm{~g}, 85 \%)$ as colourless oil: $\mathbf{R}_{\mathbf{f}} 0.65$ (petroleum ether/EtOAc 50:50, $\mathrm{KMnO}_{4}$ ); $\delta_{\mathbf{H}}\left(500 \mathrm{MHz}, \mathrm{CDCl}_{3}\right) 5.88(1 \mathrm{H}, \mathrm{s}, \mathrm{H}-4), 4.65\left(2 \mathrm{H}, \mathrm{d},{ }^{3} J_{\mathrm{HH}} 6.0\right.$, $\mathrm{H}-6), 3.96(3 \mathrm{H}, \mathrm{s}, \mathrm{H}-7), 2.20($ br s, $1 \mathrm{H},-\mathrm{OH}) ; \delta_{\mathrm{C}}\left(\mathrm{CDCl}_{3}, 125\right.$ MHz) 172.5 (C-3), 172.4 (C-5), 93.2 (C-4), 57.1 (C-6), 56.7 (C-7). HRMS $m / z\left(\mathrm{APCI}^{+}\right)$, found: $[\mathrm{M}+\mathrm{H}]^{+} 130.0496, \mathrm{C}_{5} \mathrm{H}_{8} \mathrm{NO}_{3}$ requires
$[\mathrm{M}+\mathrm{H}]^{+}$130.0496. These data are in accordance with the literature. ${ }^{23,24}$

\subsection{Synthesis of 3-methoxy-5-(methoxymethyl)isoxazole $(4)^{25}$}

$\mathrm{NaH}$ (60\% dispersion in mineral oil, $232 \mathrm{mg}, 5.80 \mathrm{mmol}, 1.1 \mathrm{eq})$ was added in single portion to a solution of 5-hydroxymethyl-3-methoxyisoxazole (3) $(680 \mathrm{mg}, 5.27 \mathrm{mmol}$, $1.0 \mathrm{eq})$ in $\mathrm{THF}(30 \mathrm{~mL})$ at $0{ }^{\circ} \mathrm{C}$. The reaction mixture was stirred at $\mathrm{rt}$ for $1 \mathrm{~h}$, cooled to $0{ }^{\circ} \mathrm{C}$ and $\mathrm{CH}_{3} \mathrm{I}(0.36 \mathrm{~mL}, 5.80 \mathrm{mmol}$, $1.1 \mathrm{eq)}$ was added. After $1 \mathrm{~h}$ stirring at $\mathrm{rt}$, the reaction was quenched by slow addition of ice-cold water $(30 \mathrm{~mL})$. The aqueous layer was extracted into EtOAc $(4 \times 20 \mathrm{~mL})$. The combined organic layers were washed with brine $(20 \mathrm{~mL})$, dried over $\mathrm{MgSO}_{4}$, filtered and concentrated under reduced pressure. The resulting yellow oil was purified by silica gel column chromatography (petroleum ether/ $\mathrm{Et}_{2} \mathrm{O}, 80: 20$ ) to afford 3-methoxy-5-(methoxymethyl)isoxazole (4) (473 $\mathrm{mg}, 57 \%)$ as a colourless oil: $\mathbf{R}_{\mathbf{f}} 0.52$ (petroleum ether/ $\mathrm{Et}_{2} \mathrm{O}, 70: 30, \mathrm{KMnO}_{4}$ ); FT-IR $\left(\right.$ ATR $\left.\mathrm{cm}^{-1}\right)$ 2949, 1620, 1516, 1454, 1411, 1382, 1098, $1030,966,916,795 ; \delta_{\mathbf{H}}\left(500 \mathrm{MHz}, \mathrm{CDCl}_{3}\right) 5.88(1 \mathrm{H}, \mathrm{s}, \mathrm{H}-4)$, $4.42(2 \mathrm{H}, \mathrm{s}, \mathrm{H}-6), 3.97(3 \mathrm{H}, \mathrm{s}, \mathrm{H}-8), 3.42(3 \mathrm{H}, \mathrm{s}, \mathrm{H}-7) ; \delta_{\mathbf{C}}\left(\mathrm{CDCl}_{3}\right.$, $125 \mathrm{MHz}) 172.5$ (C-3), 170.3 (C-5), 94.4 (C-4), 65.8 (C-6), 58.9 (C-7), $57.2 \quad(\mathrm{C}-8) ; \quad$ HRMS $\mathrm{m} / z \quad\left(\mathrm{ESI}^{+}\right)$, found: $[\mathrm{M}+\mathrm{H}]^{+} 144.0651, \mathrm{C}_{6} \mathrm{H}_{10} \mathrm{NO}_{3}$ requires $[\mathrm{M}+\mathrm{H}]^{+}$144.0661. These data are in accordance with the literature. ${ }^{25}$

\subsection{Synthesis of 4-iodo-3-methoxy-5- (methoxymethyl)isoxazole (5)}

NIS (997 mg, $4.43 \mathrm{mmol}, 1.5 \mathrm{eq}$ ) was added to a solution of 3-methoxy-5-(methoxymethyl)isoxazole (4) (422 mg, $2.95 \mathrm{mmol}$, $1.0 \mathrm{eq})$ in TFA $(10 \mathrm{~mL})$. After stirring at rt overnight, the solvent was removed under reduced pressure and the residue was purified by silica gel column chromatography (petroleum ether/Et ${ }_{2} \mathrm{O}$, 90:10), affording 4-iodo-3-methoxy-5-(methoxymethyl)isoxazole (5) $(696 \mathrm{mg}, 88 \%)$ as colourless crystalline solid: $\mathbf{R}_{\mathbf{f}} 0.50$ (petroleum ether/ $\mathrm{Et}_{2} \mathrm{O}, 70: 30, \mathrm{UV} / \mathrm{KMnO}_{4}$ ); $\mathbf{m p} 88-89^{\circ} \mathrm{C}$; FT-IR $\left(\right.$ ATR, $\left.\mathrm{cm}^{-1}\right)$ 2990, 1609, 1526, 1447, 1408, 1371, 1277, 1192, $1105,1086,1053,959,947,928,783,716,546 ; \delta_{\mathrm{H}}(500 \mathrm{MHz}$, $\left.\mathrm{CDCl}_{3}\right) 4.47$ (2H, s, H-6) 4.03 (3H, s, H-8), 3.40 (3H, s, H-7); $\delta_{\mathrm{C}}\left(125 \mathrm{MHz}, \mathrm{CDCl}_{3}\right) 171.5(\mathrm{C}-3), 169.8(\mathrm{C}-5), 64.8(\mathrm{C}-6), 59.0$ (C-7), 57.8 (C-8), 51.7 (C-4); HRMS $m / z$ (ESI ${ }^{+}$, found: $[\mathrm{M}+\mathrm{H}]^{+}$ $269.9619, \mathrm{C}_{6} \mathrm{H}_{9} \mathrm{NO}_{3}{ }^{127} \mathrm{I}$ requires $[\mathrm{M}+\mathrm{H}]^{+} 269.9627$.

\subsection{Synthesis of (3-methoxy-5-(methoxymethyl)isoxazol- 4-yl) (4-methoxyphenyl)iodonium tetrafluoroborate (6)}

4-Iodo-3-methoxy-5-(methoxymethyl)isoxazole (5) (70 mg, $0.26 \mathrm{mmol}, 1.0 \mathrm{eq})$ and $\mathrm{BF}_{3} \cdot \mathrm{Et}_{2} \mathrm{O}(80 \mu \mathrm{L}, 0.65 \mathrm{mmol}, 2.5 \mathrm{eq})$ were added to a solution of $m \mathrm{CPBA}$ (70\% active oxidant, $83 \mathrm{mg}, 0.34$ mmol, $1.3 \mathrm{eq})$ in DCM $(1.5 \mathrm{~mL})$ at $\mathrm{rt}$. The resulting yellow solution was stirred at $\mathrm{rt}$ for $2 \mathrm{~h}$ and cooled to $0{ }^{\circ} \mathrm{C}$, 4-methoxyphenylboronic acid (43 mg, $0.29 \mathrm{mmol}, 1.1 \mathrm{eq}$ ) was added and the temperature was allowed to warm to rt. After $2 \mathrm{~h}$ of stirring, the crude mixture was applied on silica plug $(0.8 \mathrm{~g})$ and eluted with DCM $(10 \mathrm{~mL})$ to remove unreacted ArI (5) and $m \mathrm{CBA}$ followed by (DCM/MeOH) $(20: 1 \mathrm{v} / \mathrm{v}$ mixture, $42 \mathrm{~mL})$ to elute the product, leaving any boronic acid derivatives on the column. The latter solution was concentrated and $\mathrm{Et}_{2} \mathrm{O}(1 \mathrm{~mL})$ was added to the residue to induce precipitation. The ether phase was decanted and the solid was washed twice more with $\mathrm{Et}_{2} \mathrm{O}(2 \times 1 \mathrm{~mL})$ and dried in vacuo to give (3-methoxy-5-(methoxymethyl)isoxazol-4-yl) (4-methoxyphenyl)iodonium tetrafluoroborate salt (6) in $(60 \mathrm{mg}$, $50 \%$ ) as a pale yellow solid: $\mathbf{m p} 161-163{ }^{\circ} \mathrm{C}$ (dec.); FT-IR (ATR, $\mathrm{cm}^{-1}$ ) 2945, 1601, 1497, 1408, 1246, 1088, 1039, 756, 692; $\delta_{\mathrm{H}}\left(500 \mathrm{MHz}, d_{6}\right.$-DMSO $) 8.00\left(2 \mathrm{H}, \mathrm{d},{ }^{3} J_{\mathrm{HH}} \quad 8.9, \mathrm{H}-10\right)$, 
$7.08\left(2 \mathrm{H}, \mathrm{d},{ }^{3} J_{\mathrm{HH}} 8.9, \mathrm{H}-11\right), 4.79(2 \mathrm{H}, \mathrm{s}, \mathrm{H}-6), 4.02(3 \mathrm{H}, \mathrm{s}, \mathrm{H}-8)$, $3.80(3 \mathrm{H}, \mathrm{s}, \mathrm{H}-13), 3.38(3 \mathrm{H}, \mathrm{s}, \mathrm{H}-7) ; \delta_{\mathrm{C}}\left(125 \mathrm{MHz}, d_{6}\right.$-DMSO $)$ 174.4 (C-5), 169.6 (C-3), 162.0 (C-12), 136.9 (C-10), 117.6 (C-11), 106.7 (C-9), 78.0 (C-4), 64.6 (C-6), 58.8 (C-7), 58.6 (C-8), $55.8(\mathrm{C}-13) ; \quad \delta_{\mathbf{F}}\left(470 \mathrm{MHz}, d_{6}\right.$-DMSO $)-148.17, \quad-148.23$

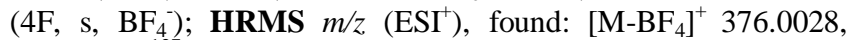
$\mathrm{C}_{13} \mathrm{H}_{15} \mathrm{NO}_{4}{ }^{127}$ I requires [M-BF $]^{+}$376.0040].

\subsection{Synthesis of mesityl(3-methoxy-5- (methoxymethyl)isoxazol-4-yl)iodonium tetrafluoroborate $(7)$}

4-Iodo-3-methoxy-5-(methoxymethyl)isoxazole (5) (70 mg, 0.26 mmol, $1.0 \mathrm{eq})$ and $\mathrm{BF}_{3} \cdot \mathrm{Et}_{2} \mathrm{O}(80 \mu \mathrm{L}, 0.65 \mathrm{mmol}, 2.5 \mathrm{eq})$ were added to a solution of $m$ CPBA (70\% active oxidant, $83 \mathrm{mg}, 0.34$ mmol, $1.3 \mathrm{eq})$ in DCM $(1.5 \mathrm{~mL})$ at $\mathrm{rt}$. The resulting yellow solution was stirred at $\mathrm{rt}$ for $2 \mathrm{~h}$ and cooled to $0{ }^{\circ} \mathrm{C}$, 2,4,6-trimethylphenylboronic acid (48 mg, $0.29 \mathrm{mmol}, 1.1 \mathrm{eq}$ ) was added and the temperature was allowed to warm to rt. After $2 \mathrm{~h}$ of stirring, the crude mixture was applied on silica plug $(0.8 \mathrm{~g})$ and eluted with DCM $(10 \mathrm{~mL})$ to remove unreacted ArI (5) and $m \mathrm{CBA}$ followed by $(\mathrm{DCM} / \mathrm{MeOH})(20: 1 \mathrm{v} / \mathrm{v}$ mixture, $42 \mathrm{~mL})$ to elute the product, leaving any boronic acid derivatives on the column. The latter solution was concentrated, and $\mathrm{Et}_{2} \mathrm{O}(1 \mathrm{~mL})$ was added to the residue to induce precipitation. The ether phase was decanted and the solid was washed twice more with $\mathrm{Et}_{2} \mathrm{O}(2 \times 1 \mathrm{~mL})$ and dried in vасио to give mesityl(3-methoxy-5(methoxymethyl)isoxazol-4-yl)iodonium tetrafluoroborate salt (7) in $(55 \mathrm{mg}, 45 \%)$ as a pale yellow solid: ; $\mathbf{m p ~} 157-160{ }^{\circ} \mathrm{C}$ (dec.); FT-IR $\left(\mathrm{ATR}, \mathrm{cm}^{-1}\right)$ 2916, 1607, 1470, 1377, 1032, 1003, 962, 835,$687 ; \delta_{\mathbf{H}}\left(500 \mathrm{MHz}, d_{6}\right.$-DMSO $) 7.20(2 \mathrm{H}, \mathrm{s}, \mathrm{H}-12)$, $4.72(2 \mathrm{H}, \mathrm{s}, \mathrm{H}-6), 3.96(3 \mathrm{H}, \mathrm{s}, \mathrm{H}-8), 3.37$ (3H, s, H-7), $2.63(6 \mathrm{H}, \mathrm{s}, \mathrm{H}-11), 2.29(3 \mathrm{H}, \mathrm{s}, \mathrm{H}-14) ; \delta_{\mathrm{C}}\left(125 \mathrm{MHz}, d_{6}\right.$-DMSO) 174.3 (C-5), 169.9 (C-3), 143.0 (C-13), 141.5 (C-10), 129.6 (C-12), 123.9 (C-9), 75.9 (C-4), 64.7 (C-6), 58.9 (C-7), 58.5 (C-8), $26.0 \quad(\mathrm{C}-11), \quad 20.5 \quad(\mathrm{C}-14) ; \quad \delta_{\mathrm{F}} \quad\left(470 \quad \mathrm{MHz}, \quad d_{6}\right.$-DMSO $)$ $-148.16,-148.21\left(4 \mathrm{~F}, \quad \mathrm{~s}, \mathrm{BF}_{4}^{-}\right) ; \mathbf{H R M S} \mathrm{m} / \mathrm{z}\left(\mathrm{ESI}^{+}\right)$, found: $\left[\mathrm{M}_{-} \mathrm{BF}_{4}\right]^{+}$388.0392, $\mathrm{C}_{15} \mathrm{H}_{19} \mathrm{NO}_{3}{ }^{127} \mathrm{I}$ requires $\left[\mathrm{M}-\mathrm{BF}_{4}\right]^{+}$388.0404.

The chemical structures and numbering of the synthesized compounds are shown in Table $\mathbf{1}$.

Table 1: Structures assigned to synthesized compounds

Compound Structure Compound

\subsection{Result and discussion}

The synthesis of iodoisoxazole (5) is illustrated in Scheme 1. Ester (2) was synthesized from the commercially available isoxazole (1).
Protection of (1) as a methyl ether afforded methyl ester (2). Reduction of (2) with $\mathrm{NaBH}_{4}$ in $\mathrm{MeOH}$ afforded alcohol (3) in good yield and then conversion of (3) to its methyl-ether derivative (4) was carried out with methyl iodide and sodium hydride. This reaction afforded (4) in acceptable yield (57\%). Iodination of methyl ether (4) was carried out with NIS in TFA. The desired product (5) was isolated in good yield (88\%) and its structure was confirmed by X-ray crystallography (ball-and-stick representation) (Scheme 1). The summary of crystal data and structure refinement parameters for iodoisoxazole (5) are shown in Table $\mathbf{2}$
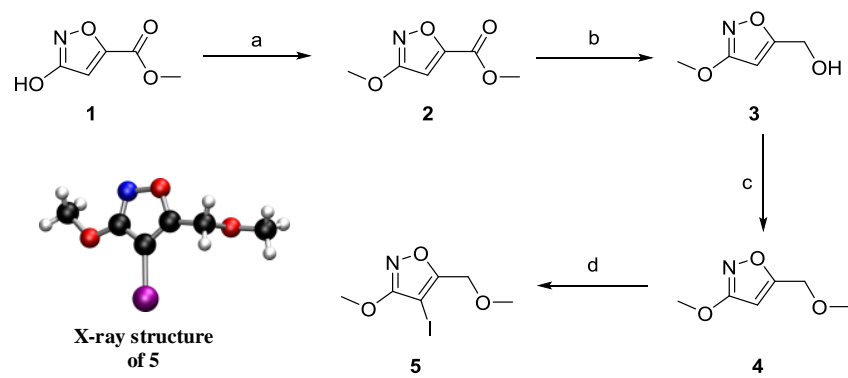

Scheme 1: Synthesis of iodoisoxazole (5). Reagents and conditions: a) MeI, $\mathrm{K}_{2} \mathrm{CO}_{3}, \mathrm{DMF}, 14 \mathrm{~h}, 66 \%$; b) $\mathrm{NaBH}_{4}, \mathrm{MeOH}$ rt, overnight, $85 \%$; c) $\mathrm{NaH}$ (60\% dispersion oil), MeI, THF, $0{ }^{\circ} \mathrm{C} \rightarrow \mathrm{rt}, 1 \mathrm{~h}, 57 \%$; d) NIS, TFA, rt, overnight, $88 \%$.

Table 2: Crystal data and structure refinement parameters for iodoisoxazole (5)

\begin{tabular}{|c|c|}
\hline Crystal parameters & 5 \\
\hline Formula & $\mathrm{C}_{6} \mathrm{H}_{6} \mathrm{INO}_{4}$ \\
\hline Molecular weight & 283.02 \\
\hline Crystal description & Colourless platelet \\
\hline Crystal dimensions (mm) & $0.21 \times 0.12 \times 0.02$ \\
\hline Crystal system & Monoclinic \\
\hline Space group & $P 2_{1} / n$ \\
\hline $\mathrm{a}(\AA)$ & $4.1252(13)$ \\
\hline $\mathrm{b}(\AA)$ & $15.712(4)$ \\
\hline c $(\AA)$ & $13.231(4)$ \\
\hline$\alpha\left(^{\circ}\right)$ & \\
\hline$\beta\left(^{\circ}\right)$ & $95.941(9)$ \\
\hline$\gamma\left({ }^{\circ}\right)$ & \\
\hline Volume $\left(\AA^{3}\right)$ & $853.0(4)$ \\
\hline $\mathrm{Z}$ & 4 \\
\hline Calculated density $\left(\mathrm{g} \mathrm{cm}^{-3}\right)$ & 2.204 \\
\hline Temperature $(\mathrm{K})$ & 173 \\
\hline$\mu\left(\mathrm{mm}^{-1}\right)$ & 3.731 \\
\hline $\mathrm{F}(000)$ & 536 \\
\hline Reflections collected & 9717 \\
\hline Unique reflections $\left(R_{\text {int }}\right)$ & $1549(0.1853)$ \\
\hline Max./min. transmission & $0.928,0.181$ \\
\hline$R_{1}, w R_{2}[I>2 \sigma(I)]$ & $0.0964,0.2438$ \\
\hline$R_{1}, w R_{2}$ (all data) & $0.1131,0.2514$ \\
\hline Goodness of fit & 0.985 \\
\hline Data/restraints/parameters & $1549 / 0 / 112$ \\
\hline Max. difference peak/hole $\left(\mathrm{e} \mathrm{A}^{-3}\right)$ & $3.89,-1.97$ \\
\hline
\end{tabular}

\subsection{One-pot synthesis of diaryliodonium tetrafluoroborate salts (6) and (7)}

A one-pot synthesis of the tetrafluoroborate iodonium salt was investigated. Such a protocol has been shown to be efficient in generating such salts without anion-exchange step. ${ }^{26}$ Accordingly, a solution of $m$ CPBA $(1.3 \mathrm{eq})$ in DCM was treated with iodoisoxazole (5) $(1.0 \mathrm{eq})$ and boronic acid precursors (1.1 eq) in the presence of boron trifluoride $(2.5 \mathrm{eq})$ at room temperature. Diaryliodonium tetrafluoroborate salts $(\mathbf{6})$ and $(7)$ were obtained in acceptable yields upon precipitation with diethyl ether (Scheme 2). 


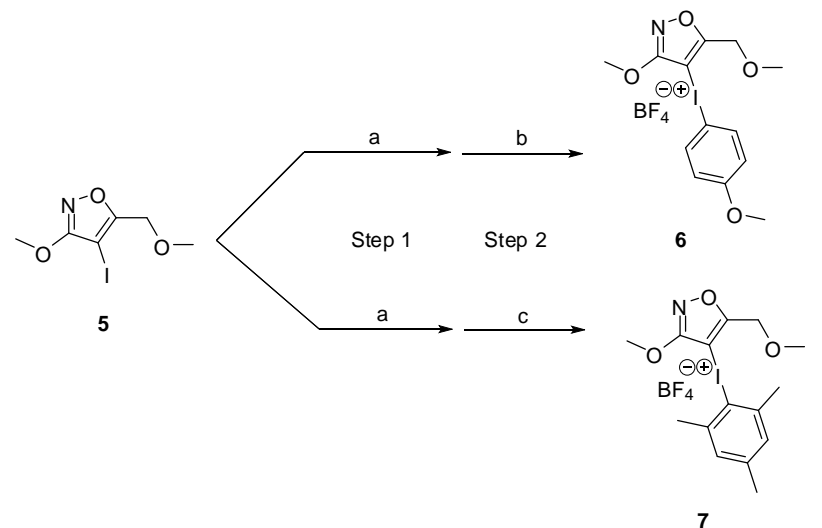

Scheme 2: One-pot synthesis of iodonium tetrafluoroborate salts (6) and (7). Reagents and conditions: a) $m \mathrm{CPBA}, \mathrm{BF}_{3} \cdot \mathrm{OEt}_{2}, \quad \mathrm{rt}, 2 \mathrm{~h}$ b) $4-\mathrm{OMePh}-\mathrm{B}(\mathrm{OH})_{2}$, rt, 2 h, 50\%; c) 2,4,6-TriMePh-B $(\mathrm{OH})_{2}, \mathrm{rt}, 2 \mathrm{~h}, 45 \%$.

Despite a wide level of interest over many years in the one-pot synthesis of diaryliodonium salts, the exact mechanism remains unclear. A possible mechanism, shown in Scheme 3, starts with nucleophilic attack of iodoisoxazole (5) on $m \mathrm{CPBA}$ to generate iodo oxide (6). Further activation of $(\mathbf{6})$ by Lewis acid $\mathrm{BF}_{3}$ followed by loss of fluoride of (7), leads to intermediate (8). The free fluoride can then attack $\mathrm{BF}_{3}$ to generate $\mathrm{BF}_{4}{ }^{-}$. Intermediate $(\mathbf{8})$ then undergoes nucleophilic addition at the electrophilic iodine centre to give (9) which then collapses to afford the desired iodonium tetrafluoroborate salts.
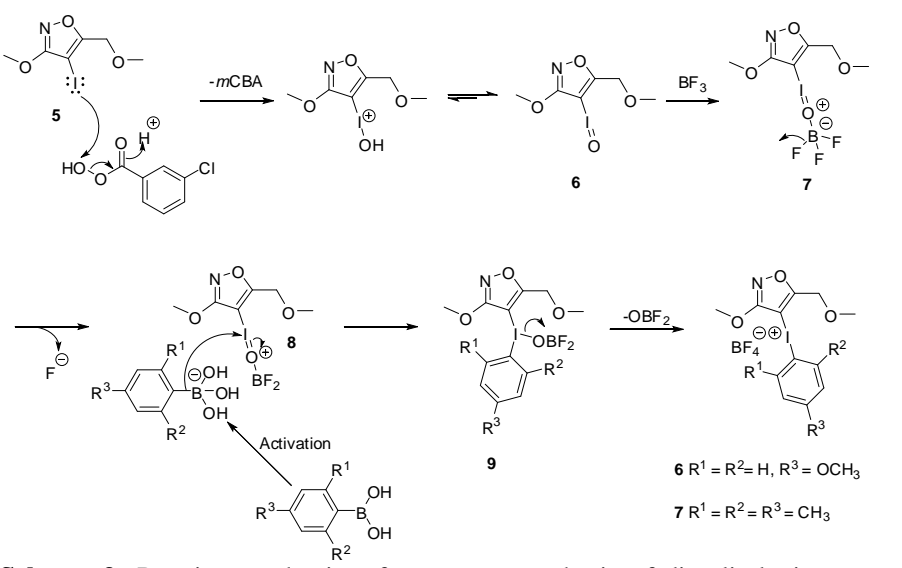

Scheme 3: Putative mechanism for one-pot synthesis of diaryliodonium tetrafluoroborate salts (6) and (7).

\section{Conclusion}

The synthesis and putative mechanism for the formation of unsymmetrical diaryl iodonium tetrafluoroborate salts have been described. This method is operationally simple and proceeded through the reaction of iodo isoxazole with a commercially available oxidant ( $m \mathrm{CPBA}$ ) in the presence of aryl boronic acids and boron trifluoride. The protocol can be extended to the synthesis of symmetrical and unsymmetrical 3,5-disubstituted isoxazole iodonium salts directly from their iodinated precursors and various aryl boronic acid derivatives.

\section{Acknowledgements}

We would like to acknowledge the financial support from Universiti Teknologi MARA and Ministry of Education Malaysia over the period of this research.

\section{References}

[1] Willgerodt, C. Ueber Einige Aromatische Jodidchloride; J. Prakt. Chem. 1886, 33, 154-160.

[2] Willgerodt, C. Zur Kenntniss Aromatischer Jodidchloride, Des Jodoso-und Jodobenzols. Ber. Dtsch. Chem. Ges. 1892, 25 (2), 3494-3502.

[3] Hartmann, C.; Meyer, V. Ueber Jodobenzoësäure. Ber. Dtsch. Chem. Ges. 1893, 26 (2), 1727-1732.

[4] Hartmann, C.; Meyer, V. Ueber Eine Neue Klasse Jodhaltiger, Stickstoffreier Organischer Basen. Ber. Dtsch. Chem. Ges. 1894, 27 426-432.

[5] Merritt, E. A.; Olofsson, B. Diaryliodonium Salts: A Journey from Obscurity to Fame. Angew. Chem. Int. Ed. 2009, 48, 9052-9070.

[6] Dess, D. B.; Martin, J. C. Readily Accessible 12-I-5 Oxidant for the Conversion of Primary and Secondary Alcohols to Aldehydes and Ketones. J. Org. Chem. 1983, 48 (22), 4155-4156.

[7] Powell, W. H. Treatment of Variable Valence in Organic Nomenclature (Lambda Convention)(Recommendations 1983). Pure Appl. Chem. 1984, 56 (6), 769-778.

[8] Warnier, C.; Lemaire, C.; Becker, G.; Zaragoza, G.; Giacomelli, F.; Aerts, J.; Otabashi, M.; Bahri, M. A.; Mercier, J.; Plenevaux, A.; et al. Enabling Efficient Positron Emission Tomography (PET) Imaging of Synaptic Vesicle Glycoprotein 2A (SV2A) with a Robust and One-Step Radiosynthesis of a Highly Potent ${ }^{18}$ F-Labeled Ligand ( $\left[{ }^{18}\right.$ F $]$ UCB-H). J. Med. Chem. 2016, 59, 89558966.

[9] Hu, B.; Vavere, A. L.; Neumann, K. D.; Shulkin, B. L.; DiMagno, S. G.; Snyder, S. E. A Practical, Automated Synthesis of meta$\left[{ }^{18} \mathrm{~F}\right]$ Fluorobenzylguanidine for Clinical Use. ACS Chem. Neurosci. 2015, 6 (11), 1870-1879.

[10] Martin, J. C. "Frozen" Transition States: Pentavalent Carbon et Al. Science 1983, 221 (4610), 509-514.

[11] Perkins, C. W.; Martin, J. C.; Arduengo, A. J.; Lau, W.; Alegria, A.; Kochi, J. K. An Electrically Neutral $\sigma$-Sulfuranyl Radical from the Homolysis of a Perester with Neighboring Sulfenyl Sulfur: 9-S-3 Species'. J. Am. Chem. Soc. 1980, 102 (26), 7753-7759.

[12] Soldatova, N.; Postnikov, P.; Kukurina, O.; Zhdankin, V. V.; Yoshimura, A.; Wirth, T.; Yusubov, M. S. One-Pot Synthesis of Diaryliodonium Salts from Arenes and Aryl Iodides with OxoneSulfuric Acid. Beilstein J. Org. Chem. 2018, 14, 849-855.

[13] Zawia, E.; Hamnett, D. J.; Moran, W. J. Preparation and Synthetic Utility of Stable 1,3-Enynyl- and 1,3-Dienyl(Aryl)Iodonium Salts. J. Org. Chem. 2017, 82 (7), 3960-3964.

[14] Yusubov, M. S.; Maskaev, A. V.; Zhdankin, V. V. Iodonium Salts in Organic Synthesis. Arkivoc 2011, 1, 370-409.

[15] CrystalClear-SM Expert. Rigaku Americas, The Woodlands, Texas, USA, and Rigaku Corporation, Tokyo, Japan.

[16] CrystalAlisPro. Rigaku Oxford Diffraction, Rigaku Corporation, Oxford, U.K.

[17] Beurskens, P. T.; Beurskens, G.; de Gelder, R.; Garcia-Granda, S.; Gould, R. O.; Israel, R.; Smits, J. M. M. DIRDIF-99; Crystallography Laboratory, University of Nijmegen, The Netherlands, 1999.

[18] Burla, M. C.; Caliandro, R.; Camalli, M.; Carrozzini, B.; Cascarano, G. L.; De Caro, L.; Giacovazzo, C.; Polidori, G.; Spagna, R. SIR2004: An Improved Tool for Crystal Structure Determination and Refinement. J. Appl. Crystallogr. 2005, 38 (2), 381-388.

[19] Burla, M. C.; Caliandro, R.; Camalli, M.; Carrozzini, B.; Cascarano, G. L.; Giacovazzo, C.; Mallamo, M.; Mazzone, A.; Polidori, G.; Spagna, R. SIR2011: A New Package for Crystal Structure Determination and Refinement. J. Appl. Crystallogr. 2012, 45 (2), $357-361$.

[20] Sheldrick, G. M. Crystal Structure Refinement with SHELXL. Acta Crystallogr. Sect. C 2015, 71 (Md), 3-8.

[21] CrystalStructure v4.2. Rigaku Americas, The Woodlands, Texas, USA, and Rigaku Corporation, Tokyo, Japan, 2013.

[22] Melikian, A.; Schlewer, G.; Chambon, J. P.; Wermuth, C. G. Condensation of Muscimol or Thiomuscimol with Aminopyridazines Yields GABA-A Antagonists. J. Med. Chem. 1992, 35 (22), 4092-4097.

[23] Falch, E.; Krogsgaard-Larsen, P.; Jacobsen, P.; Engesgaard, A.; Braestrup, C.; Curtis, D. R. Synthesis, GABA Agonist Activity and Effects on GABA and Diazepam Binding of Some N-Substituted Analogues of GABA. Eur. J. Med. Chem. 1985, 20 (5), 447-453.

[24] Kempf, D. J.; Sham, H. L.; Marsh, K. C.; Flentge, C. A.; Betebenner, D.; Green, B. E.; McDonald, E.; Vasavanonda, S.; Saldivar, A.; Wideburg, N. E.; et al. Discovery of Ritonavir, a 
Potent Inhibitor of HIV Protease with High Oral Bioavailability and Clinical Efficacy. J. Med. Chem. 1998, 41 (4), 602-617.

[25] Wadoux, R. Approaches to Synthesis of Fluoromuscimol and Application Ot the Enantiomers of Benzyl Fluoride as Chiral Probes for Enzyme Reactions, MPhil Thesis, University of St Andrews, 2013.

[26] Bielawski, M.; Aili, D.; Olofsson, B. Regiospecific One-Pot Synthesis of Diaryliodonium Tetrafluoroborates from Arylboronic Acids and Aryl Iodides. J. Org. Chem. 2008, 73 (12), 4602-4607. 